\title{
"A Young Girl's Dream": Examining the Barriers Facing Female Electric Guitarists
}

\section{Monique Bourdage}

bmonique@umich.edu

Girls Rock Denver

\begin{abstract}
Critics who locate the instrument's inaccessibility to women solely in its physical design overlook cultural reasons for the lack of great female electric guitarists. The same barriers that prevent women from succeeding in other male-dominated fields also apply to the electric guitar, such as a scarcity of role models, a lack of access to education, and the masculinisation of prestigious technologies. Despite allusions to rebellion, rock ' $n$ ' roll often promotes traditional gender roles. This paper examines the creation of and efforts to break down these barriers, which have included women's music festivals, riot grrrl, and rock camps for girls.
\end{abstract}

Key words: electric guitar, women, feminism, technology, gender.

\section{Introduction}

I have a dream

what I will become

but everyone says:

she could be an actress

she could be a hairdresser

she could be a teacher, model, showgirl, artist, writer, designer.

But I have something different in mind.

I will be a Rockstar!

I even have my own guitar

and I'm such a star!

(“A Young Girl's Dream" by Sparkling Lemonade) 
The cultural and technological engineering of the electric guitar has been historically constructed to exclude women. The electric guitar's history illustrates that a technology can neither be separated from the cultural values prevalent at the time of its creation nor those cultural values later ascribed to it. Critics who locate the instrument's inaccessibility to women solely in its physical design overlook cultural reasons for the lack of great female electric guitarists. The same barriers that prevent women from succeeding in other male-dominated fields also apply to the electric guitar. These include a scarcity of role models, a lack of access to education, and the masculinisation of prestigious technologies. Innovations, both technical and cultural, have effectively effaced women's providence as appreciators of popular music while removing women from the ranks and representation of electric guitar instrumentalists in rock societies.

Up until about 1890, only traditionally trained luthiers and other skilled woodworkers were responsible for major design innovations to the guitar; however, instrument makers from nontraditional backgrounds would not greatly impact the guitar market until 1931. Many of the key players in the early drive to electrify the guitar had apprenticed under luthiers or were the sons of instrument makers. All of the innovators and company executives were men. New companies, such as Ro-Pat-In and Fender, led the market in electric guitar innovations and helped mark the transition of power in the industry from traditional instrument makers to tinkerers. However, this transition encouraged the continuation of male dominance in designing, manufacturing, and playing the electric guitar.

\section{The Masculinisation of Technology}

During the nineteenth and early twentieth centuries, cultural values held that music appreciation was a pastime relegated to women. In 1922, women still comprised the vast majority of music students and concert audiences. Likewise, guitar playing was a common hobby among women prior to the instrument's electrification (Strohm, 2004). The masculinisation of home audio technologies is a phenomenon of and reaction to post-World War II American society. Men returned from military service and used do-it-yourself (DIY) hobbyism as an outlet for the electronics skills they had gained in the armed forces. With suburban homes emphasizing togetherness, men also turned to audio hobbies as a means to reclaim specifically masculine domestic space (Keightley, 1996). Radio, with its need to be constructed and tinkered with, legitimized music appreciation for men (Douglas, 1999). Many boys and men gained knowledge about electronics through radio construction and tinkering, and this knowledge aided in the development of many other technologies including television, automobiles, and the electric guitar (Douglas, 1999; Post, 1994; Takahashi, 2000).

Ruth Oldenziel (1999) argued that the masculinisation of technology is largely a product reflective of racial, gender, and international relations in the twentieth century. Beginning in the 1890s, society increasingly looked to machines as the most important inventions. The steel and other machine-related 
industries employed few women, which distanced women from important technologies. Most patent owners were white males, and many Americans at the time accepted that women and other races naturally lacked inventive genius, which helped place technology in direct relation to white, middle class notions of manliness. These notions of manliness upheld athletes and working class men as standards and devalued women and non-white males. By the end of the 1930s, the public had inextricably linked prestigious technology and engineering, an occupation dominated by white, middle class males. The idea of powerful or prestigious technology as a male preserve firmly took hold in the public mind at a time when women entered the workforce in larger numbers than they previously had. The increase in women's mastering of machines in jobs as secretaries, factory workers, and switchboard operators, threatened male power. The acceptable feminine pursuit of technology involved the devalued technologies associated with homemaking and pink collar assembly line work. Despite evidence to the contrary, men's best defence involved attempting to erase women from the history of technology by emphasizing man's "natural" aptitude for all things technological. This attitude has succeeded in devaluing women's contributions to technological fields; enabled men to look upon any woman entering a technological field, regardless of her training and ability, as an amateur; and barred many women from access to technological pursuits.

\section{The Masculinisation of Electric Guitar Performance}

In terms of rock ' $n$ ' roll performance, the electric guitar takes on a role that Steve Waksman (1999) has termed "technophallus". Through body positioning and flamboyant physical displays, players like Jimi Hendrix fortified male dominance over the electric guitar with a large dose of phallic symbolism. Male electric guitarists often handle their instruments in ways that recall sexual acts or emphasize the phallic symbolism of their guitars. Although the guitar is most easily and comfortably played when held somewhere between the player's chest and waist, many rock guitarists play low-slung guitars held below the waist. Such positioning of the guitar makes it a much more obvious phallic symbol. Many fans and players have come to regard low-slung guitars as the only positioning that looks right. Therefore, even on women, the instrument appears as an extension of the male body, reinforcing the idea that the electric guitar should be left to male hands.

In order to earn the title of god, however, a guitarist needed to display skill along with an impressive image. In I'm a Man: Sex, Gods and Rock ' $n$ ' Roll (2000), Ruth Padel explored the metaphor of electric guitar hero as a god of rock ' $n$ ' roll by comparing this figure to the heroes of Greek mythology. She argued that because rock culture is a product of Western culture, its myths and symbols are also rooted in Western culture, and contemporary Western myths of maleness, in particular, can be ultimately traced back to the Greeks. Padel (2000, p. 23) asserted that "both rock and Greek mythology are the architecture of a highly aggressive male self-image crystallized in that word 'hero'”. Although, 
the differentiation and/or overlap of the concepts of the guitar hero and the guitar god are not always clear in rock criticism and scholarship, both metaphors denote figures worthy of idolatry and imitation.

While the idea of the rock god grew out of 1960s counterculture music, the counterculture shared the dominant tendency to marginalize women and did little to offer women participation beyond traditional gender roles. As interpreted by Sheila Whiteley (2000, p.23), "both the lifestyle and the musical ethos of the period undermined the role of women, positioning them as either romanticized fantasy figures, subservient earth mothers or easy lays". Freedom for women consisted of free love, an idea easily conflated with the notion of the active female. However, as Whiteley (2000, p. 54) asserts, since this freedom continued to be defined in terms of male sexuality, "a woman who wholeheartedly embraced the dictum of unlimited fucking remained, essentially, submissive". Few women gained stardom in rock bands of the time, and those who did struggled with traditional notions of gender. Whiteley (2000, pp. 23-24) provides the following examples: Janis Joplin's early demise has widely been documented to have been the result of her struggle to be "one of the boys"; Cass Elliott, whose weight prevented her from being sexualized within traditional notions of feminine beauty, was afforded a matronly image with the nickname "Mama Cass"; and Marianne Faithfull achieved more fame for abandoning her career in order to become Mick Jagger's girlfriend. It should be noted that none of the counterculture stars listed above played the electric guitar; rather, they remained in the feminine-coded position of singer. The generation that created the rock god along with second wave feminism simultaneously embraced traditional gender roles, which maintain barriers that prevent women from achieving success as electric guitarists.

In terms of rock ' $n$ ' roll, these traditional gender roles dictate that woman's place remain that of fan or groupie. If a woman breaks these barriers and joins a rock band, gender roles tend to relegate her to a supporting position, such as singer or bass player. Those female musicians who do play the electric guitar face many obstacles to gaining recognition for their talent. Only one of these obstacles is the fact that her gender, according to dominant social and moral values, places her at a disadvantage in the quest for god-like status.

Man/woman and masculinity/femininity are culturally coded as binary oppositions, which lead to defining the genders in terms of their differences from one another. With biblical roots illustrating that man is the origin of humanity, woman is shown as derivative of man and stands in contrast to him as "other". Additionally, the active/passive binary relationship is an essential aspect of religious dichotomies and is present in other oppositions such as pure/impure and controllable/uncontrollable. Whiteley (2000) observes that within this symbolic order, passive (controllable) women are constructed as normal whereas active women are constructed as uncontrollable and therefore unnatural. If man represents universal humanity, woman, due to her differences from man, can only represent particularities. In rock ' $n$ ' roll, these notions of particularity lead critics to treat women musicians as exceptional. Nanette Salomon (1998, pp. 
347-348) argues that "the 'exceptional' woman artist may be one of the most insidious means of undermining the likelihood of women's entering the creative arts".

Women's entrance into traditionally masculine realms upsets the status quo by threatening both the male domination of certain fields and the primacy of the gender binary system. Since the definition of woman in terms of her relationship to man arose out of patriarchal structures of culture and language, femininity is defined in a way that creates an idealized and heteronormative reflection for man. In other words, traditionally acceptable forms of femininity are those with images that reflect the feminine stereotypes imposed upon women by an androcentric culture. Whiteley (2000) interprets this to mean, men should look and act like men; i.e., active, competitive, tough, and always the victor. Women, on the other hand, should look and act like women; i.e., fragile and desirable (but only to men and never as the desirer). Active women who exhibit traits of competitiveness and strength and express themselves as not simply desirable but as also desiring are labelled as deviant within the traditional order of gender. In his study of the performance of gender in glam rock, Philip Auslander (2006, p. 217) outlines the dangers of such deviation in his assertion that "when a masculinely coded performance style is juxtaposed with a femininely coded body... figure-ground reversals that subvert reified masculine and feminine identities become possible". The easiest ways to combat such transgressions is to ignore or belittle them. As Whiteley (2000, p. 155) noted, "woman is either passive, or she doesn't exist".

Therefore, women who play the electric guitar challenge the patriarchal power structure of the music industry and larger society. Lisa L. Rhodes (2005) states that a woman can invalidate claims that electric guitar technology and rock ' $n$ ' roll are exclusively masculine domains by taking the stage and playing the electric guitar. Getting to the point of being able to take the stage, however, is not that simple. Public performance of the electric guitar requires not only drawing attention to oneself, but also doing it loudly. These traits have no place in a society that values women as passive consumers. When Patricia KennealyMorrison (1995, p. 363) wrote about her fantasy of taking the stage and "get[ting] off forty-five minutes of the indisputedly finest rock guitar ever heard anywhere" and then retiring from music, her fantasy was not directed at her inability as a woman to wield an electric guitar. Rather, it was directed toward her inability as a woman to wield that kind of freedom and power.

\section{Reclaiming/Creating Female Space}

In 1971, feminist art historian Linda Nochlin published an essay entitled "Why Have There Been No Great Women Artists?" Although the essay concerned visual artists, her arguments can easily be applied to the historical treatment of women musicians. First, Nochlin argued that critics reinforce the negative implications of the question by attempting to answer it as it is framed. In other words, feminists often make the mistake of answering the question by 
digging up examples of underappreciated female artists, which is illustrated by the plethora of books concerning women in rock that continue to be published. While it is important for scholars to draw attention to worthy female artists and musicians, the feminist scholar's work cannot end with the simple excavation of these figures. The danger with not taking the answer far enough is that the existence of these biographies can give the illusion that women have achieved equality within the field; in which case, as Nochlin pointed out, the status quo is fine as it is. ${ }^{1}$ An alternate attempt to answer the question asserts that what constitutes greatness for women is different, which leads to the assumption that there is an essentially feminine style. Such assumptions lead critics to lump all female musicians together simply by virtue of their gender and ignore the fact that these musicians actually have more in common with other musicians of their genre and era than with each other.

Paralleling Nochlin's arguments concerning visual artists, one can make the claim that there really have been no great women electric guitarists. The problem lies not in the fact that all the great players have remained hidden, but in the fact that women have institutionally been prevented from becoming great electric guitarists. Institutional barriers include a lack of female role models, traditional constructions of gender, and the masculinisation of technology in general and audio technologies in particular. Beginning with the passage of instrument-making skills from fathers to sons or young male apprentices and continuing through the masculinisation of home audio experiments and rock ' $n$ ' roll during the twentieth century, women have largely been deprived of the educational opportunities and encouragement that would lead them to pick up electric guitars let alone attempt to make a career out of playing one. The reality is that great achievement is rare for men, too. As Nochlin (1988, p. 158) asserted, the answer to the question she posed has nothing to do with individual genius; rather, the answer lies "in the nature of given social institutions and what they forbid or encourage in various classes or groups of individuals".

While the masculinisation of technology has allowed men to consider any woman an amateur in a traditionally male-dominated field, Nochlin pointed out that accusations of amateurism are also connected to a perceived lack of commitment on the part of women. This lack of commitment is alleged most notably when a woman chooses to leave or interrupt her musical career in order to focus on her marriage and family. Despite any advances women have made in terms of opening career fields over the last 40 years, Nochlin's (1988) assertion that the only role social institutions consign women to immediately is that of wife and mother still holds true. Unlike men, women face criticism and other barriers that present career and family as an either/or proposition. For example, after the birth of her daughter, interviewers repeatedly asked Suzi Quatro if motherhood meant that she would soften her image or retire from rock altogether. As Auslander (2006) noted, interviewers never thought to ask these same questions of David Bowie (or any other male musician, for that matter) after the birth of his children. 
In spite of the barriers facing women's entrance into music performance, some women have been able to create space for other women within music, such as women's music festivals, riot grrrl, and rock camps for girls. Women's music festivals grew out of second wave feminism's interest in exploring women's culture. Boden Sandstrom (2000) recalls that these festivals provided encouragement and opportunities to women both onstage and behind the scenes who had previously been denied access to instruments and other sound gear due to a lack of economic power and other barriers that prevented women from learning to use such equipment. Although the original women's music festivals took place during the 1970s, the advent of Lilith Fair in 1997 illustrated that women still lacked sufficient space and visibility within the music industry. While Lilith Fair certainly created a space supportive of women as both producers and consumers of music, its promotion of traditionally feminine artists playing feminine-coded acoustic instruments did nothing to challenge the traditional gender order, which continues to keep such women from achieving equality both in and out of the music industry. Furthermore, the very concept of "women's music" buys into the notion that there is an essentially feminine aspect of music created by women, which prevents the music from sharing critical space with that created by men.

As Gillian Gaar (1992, p. xii) points out, the very notion of "women-in-rock" ensures that these musicians "are still by and large defined in that order-as women first, and rock performers second". Such classification allows each female musician that comes to the attention of mainstream critics and audiences to be dismissed as a trend. It is this means of othering coupled with the assumption that there are essentially feminine and masculine modes of rebellion that leads to the false impression that women's contributions to rock have been episodic rather than part of a cohesive history. Each decade since the advent of rock ' $n$ ' roll has seen its share of female musicians treated as novelties or trends, a fact which necessitates the acknowledgment that women musicians have always played a part in the history of rock.

In The Sex Revolts: Gender, Rebellion, and Rock ' $n$ ' Roll (1995), Simon Reynolds and Joy Press argue:

...whereas the prototypes and precursors of male rock rebellion are easy to locate, the ancestors for female rock rebellion are rather more elusive. Instead of clearly defined trajectories (e.g. the beats/Jim Morrison/lggy Pop/Nick Cave lineage), female rebellion is a kind of subterranean river that wells up unexpectedly from time to time, seemingly out of nowhere, then disappears below the surface again (p. 230).

By "ancestors for female rock rebellion", Reynolds and Press seem to mean historical examples of female rock rebels (that is, a lack of female role models); however, the above quote and the authors subsequent discussion of four strategies used in female rock rebellion allude to the often made but misguided assumption that there is an essentially feminine form of rock rebellion. 
To assert this would be to assert that women musicians have more in common with each other merely by virtue of their gender than with male performers within their respective genres. Reynolds and Press (1995, pp.232-233) go on to provide an example of a trajectory that runs from Suzi Quatro to Joan Jett to L7. While such trajectory claims are simply trying to illustrate characteristics shared by certain female musicians, many critics seem to take such gender-exclusive trajectories as gospel, failing to take into account the fact that some female musicians may indeed hail from the the same rebellious lineage as Iggy Pop and Nick Cave. In fact, Donita Sparks, former L7 guitarist, taught herself to play by listening to albums by the Ramones, which demonstrates that a musician's rebellious lineage does not need to be gender-exclusive. The type of reasoning that assumes that a female musician's role models must also be female is in line with the binary opposition that designates males as active producers and females as passive consumers. As explained by Simon Frith and Angela McRobbie (2000), males consume actively by attempting to become the rock star, and females consume passively by dreaming about providing companionship to the rock star. In other words, to attempt to become a rock star is to engage in a masculine activity.

Even when allowed to claim such lineage, female musicians must face the fact, as Reynolds and Press (1995, p. 234) state, that "[t]o be a woman is to be torn between the fact of biology and the fiction of femininity". It is this "fiction of femininity", the fact that gender is a constant process of construction that must simultaneously contend with stereotypes cemented long ago, which enables the contributions of female musicians to be most readily diminished through critics' complaints regarding their failure to conform to established gender norms. Within the fiction of femininity, women are not permitted to be loud, sweat, have callused hands, or otherwise draw attention to themselves in ways requisite of electric guitarists. Women who display such characteristics face having the authenticity of their performance called into question. For example, leather-clad rockers like Quatro and Jett (along with countless other musicians receiving the "tomboy" label) have been dismissed as emulating male rebellion, and the Runaways were called "jailbait rockers" by critics who would not have blinked an eye at sexually charged lyrics from a band comprised entirely of teenage boys. Because the vast majority of electric guitar players are male, electric guitarists, male and female alike, are judged on playing standards established by men. A woman who plays like "one of the boys" seems to be appropriating a "masculine" style while men are seen as carrying on the traditions of rock performance. Speaking of women who play "authentic" rock, Norma Coates (1997, p.53) asserts, "Such violations of the invisible yet potent rules of power in rock result in the mobilisation of tropes of 'traditional' femininity to keep women firmly in their marginal place in rock".

The riot grrrl movement was one way in which the underground offered women space to express unconventional images of femininity. Judith Halberstam (2002) notes that, unfortunately, critics usually construct the history so that the movement appears to be derivative of male-dominated punk rock. Such a construction reinforces the assumption that music created by men is 
authentic while that created by women must prove that it is so. It also fails to account for the fact that riot grrrl bands have more in common with male musicians of the underground than with their mainstream female contemporaries.

Although generally traced to female bands coming out of Olympia, Washington, and Washington, D.C., around 1991, riot grrrl was intended as a feminist, political movement of which music was merely one component. Kathleen Hanna, who headed a riot grrrl band and a zine, both named Bikini Kill, authored and published the Riot Grrrl Manifesto. The manifesto contradicted the notion that young women growing up in the United States of the 1990s were living in a postfeminist era. It outlined a wide variety of reasons that a new feminist movement was necessary, such as, "BECAUSE we are angry at a society that tells us Girl=Dumb, Girl=Bad, Girl=Weak". Riot grrrl recognized that young women continued to face abuse, rape, eating disorders, and other topics generally considered taboo. Maria Raha (2005) asserts that through zines, music, and art, the movement sought to create a safe space for girls to discuss their experiences and redefine girlhood on their own terms. As Kristen Schilt (2003, p.14) argues in an article on the mainstream's appropriation of riot grrrl culture, the movement revolutionized the idea that girl culture begins and ends in the bedroom by "making the bedroom a place to produce zines, hold all-girl meetings, or play guitar".

By the mid-1990s, mainstream press had all but forgotten about the riot grrrl phenomenon and focused instead on promoting the angry women of rock. Alanis Morissette, Fiona Apple, Meredith Brooks, Tracy Bonham, and a host of others comprised what Raha $(2005$, p. 223) calls "a string of attractive young women armed with guitars and a softer, cleaner feminist bent that tidied up riot grrrl's grit". These artists channelled their anger through acceptably postfeminist images, which meant they gave the illusion of feminist independence while clinging to traditional feminine ideals. Raha (2005, p. 224) summed up the postfeminist contradictions of these angry women as follows: "for all their whispered 'fuck you's, they teetered on a feminist tightrope, revealing both their strongest and most stereotypical sides when it came to love and rejection".

According to Amelia Jones (1998, p. 387), the danger of postfeminist imagery lies in its redefinition of "femininity, feminism, and even masculinity in relation to racist, class-bound, and patriarchal models of gender and sexual identity". Postfeminism defuses advances toward the acceptance of polysemic femininity by falsely promoting the notion that society has moved beyond feminism. Jones (1998) claims this promotes the idea that women have earned the right to choose to embrace traditional gender roles, and this notion acts to suppress other forms of feminism. As argued throughout this paper, the greatest barriers to women achieving equality in any field are those social institutions that reinforce the binary opposition of gender.

Despite all efforts, postfeminism and its palatable versions of female anger have not succeeded in defusing the underground's drive to embrace polysemic femininity. Raha (2005) asserted: 
As long as sort-of-angry-but-still-camera-and-fashion-friendly women like Gwen Stefani receive mainstream accolades for being 'different', there will always be room for one more story about intelligent, questioning, truly subversive, sometimes feminist, angry, hard-working, creative individuals transgressing cultural boundaries ( $p$. xix).

Although the mainstream may not offer images of women that do much to challenge the traditional gender order, as long as it feels the need to answer the underground by providing more acceptable images of femininity, the fact remains that women become more visible as musicians.

A prime example of this drive occurred in 2000 when Misty McElroy founded the Rock ' $n$ ' Roll Camp for Girls in Portland, Oregon, which influenced the development of other such camps and spawned the creation of the Girls Rock Camp Alliance in February 2007. As of March 2010, the Girls Rock Camp Alliance boasted twenty-five affiliate and nine pending affiliate camps across North America and in Europe and had knowledge of eight other camps currently forming, which will expand the reach of these organizations to include South America and New Zealand. The point of these programs is not just to teach girls how to play rock ' $n$ ' roll; it is to empower girls, build self-esteem, and provide them access to equipment and instruction that has previously been denied them due to their gender and/or socioeconomic background. As summed up in the mission of the Willie Mae Rock Camp in New York City, "We want to encourage them to explore the openness and freedom and fighting spirit of homemade music, and make it their own. And we want them to carry that feeling with them in whatever they do".

\section{Conclusions}

A recent business article in USA Today claims, "the guitar-making industry...has long been thwarted trying to tap the elusive market for female guitarists" (Krantz 2009). Considering manufacturers' misdirected attempts at reaching this "elusive" market, the industry's lackluster results are less than surprising. The most visible recent efforts to increase the number of female electric guitarists, however, tend to focus on the design of the instrument rather than its meaning in popular culture. Manufacturers, such as Fender and Gibson, have recently released models with designs geared toward women. In January 2006, Gibson announced the release of the SG Goddess and Les Paul Vixen, which were versions of the standard SG and Les Paul models, respectively, updated to appeal to women. Gibson's website indicates the updates included lighter bodies, thinner necks, and availability in colours such as coral.

According to a Gibson press release, in 2007, the guitar manufacturer partnered with Agent Provocateur, a lingerie shop, to promote the Goddess. Photos accompanying one of Gibson's articles about the partnership depict window displays featuring pastie- and panty-clad mannequins draped over 
keyboards and wearing the pink and purple guitars like accessories-images that connote that a woman actually playing a guitar is as wild a fantasy as any inspired by the lingerie. In another Gibson-produced article of 2007, Eric Marlow, a Gibson employee for 17 years at the time, credits the female-targeted guitars as more of the "outside-the-box" thinking that has characterized Gibson's history. Russell Hall, the article's author, states, "In the tradition of Gibson's '50s spaceage guitars - the Flying Vs, the Explorers, and the like-such designs evidence a willingness to take risks with regard to public acceptance". This assertion is problematic in at least two ways: 1) it celebrates the fact that it is not publicly acceptable to market guitars to women and 2) it fails to acknowledge that Gibson's space-age guitars did not gain public acceptance for 20 years after their release. At the time of writing, both the Goddess and Vixen models have been discontinued. Andy Rossi, Fender's senior vice president of global sales and marketing, recently stated, "...creating an instrument that is specialized for females is pandering, insulting and not what females want" (Krantz 2009). Considering that Fender's most notable attempts at designs marketed to women have been its Squier Stratocaster models bearing the likeness of Hello Kitty, the company would do well to heed Rossi's advice that "[w]omen want real guitars, not toys".

Tish Ciravolo founded Daisy Rock in 2000 in a self-described attempt to "level the playing field" for female guitarists. While on the surface, Daisy Rock appears to be making progress by encouraging girls as young as six to play the electric guitar, the company produces bodies shaped like hearts, flowers, butterflies, and stars. A guitar with a more traditionally shaped body bore the model name Tom Boy. As of this writing, Daisy Rock has discontinued this model and appears to favour the name "Rebel" in marketing such guitars. Additionally, Daisy Rock's guitars come in shades of pink, purple, blue, and yellow and often feature a glittery finish. Such innovations seem to imply that the real barrier to preventing more females from becoming guitarists stems from the instrument's lack of frilliness. Even Gibson's female-targeted models reflect the idea that the way to eliminate barriers between women and electric guitars is through a pastel paint job. While Daisy Rock's guitars may capitalize on the idea that girls do not have to give up their femininity to play electric guitars, focus on the instrument's design only distracts from the real issue. The company's designs reinforce traditional gender roles by defining femininity through a narrow range of shapes and colours and by labelling those female musicians who prefer traditional guitar designs as more masculine than the rest of Daisy Rock's customers. The argument misses the point that the solution lies in the cultural history of the technology rather than the technology itself.

While all of the above manufacturers sponsor both male and female guitarists, only Daisy Rock currently offers a signature model honouring female artists (the Bangles). Fender's artist series features twenty-six guitars representing twenty-two male and no female musicians, and Gibson's custom line offers guitars honouring thirteen male musicians. While Gretsch's guitar site depicts two women holding but not playing guitars, the company offers instruments honouring fifteen guitarists, none of whom are female. This does not 
mean that female guitarists have never had signature models named after them. In 1996, Bonnie Raitt became the first woman to have a signature Fender Stratocaster bearing her name; however, this model is no longer in production.

That year, Raitt also had the honour of being the only woman mentioned in an exhibit on the history of the electric guitar sponsored by the Smithsonian, which claimed "thanks to pioneers like Bonnie Raitt, women have earned an equal place in what had traditionally been a male-dominated field". The companion program to the exhibit names ten male guitarists in addition to Raitt. Recognition of female guitarists had doubled by 2003, when Rolling Stone's list of "The 100 Greatest Guitarists of All Time" ranked Joni Mitchell at seventy-two and Joan Jett at eighty-seven. In 2004, female musicians accounted for a mere $7 \%$ of guitar sales (Segal 2004). Recent estimates indicate that the figure is now near 10\% (Krantz 2009).

In addition to sexist marketing campaigns and an institutional lack of appreciation for female guitarists, the industry must consider that another reason female guitarists seem like an elusive market is that most large guitar retailers promote an atmosphere and attitude that give women the impression they missed the "no girls allowed" sign on the way in the door. The works of Mavis Bayton and Mina Carson et al. (2004) contain numerous first-hand accounts of women musicians, both novices and professionals, being ignored, belittled, and otherwise frustrated by their experiences both shopping and working in guitar stores. Moreover, few promotional or instructional items in these stores depict women actually playing guitars. Tish Ciravolo's husband, Michael, is the president of Schechter Guitars, but this industry connection, which allowed Daisy Rock into trade shows in its early days, did little to gain Daisy Rock acceptance by retailers. Since Ciravolo partnered with Alfred Music Publishing to write guitar instruction books for girls, the publisher has used its retail relationships to negotiate shelf space for the so-called "girl guitars" (Krantz 2009).

Nevertheless, the fact that men designed the electric guitar remains too simple an explanation for men's continued dominance over the instrument. The real barriers preventing female electric guitarists from gaining recognition as credible musicians are the same barriers women face when entering other professions. These barriers include the underlying assumption that women are inferior to men, the tendency to link powerful technologies to masculinity, and the subsequent tendency to treat women as amateurs in technological fields regardless of their training and talent. As Coates (1997, p. 52) points out, "what is reiterated in and by rock is a particular type of masculinity, one which was 'fixed' in the early days of rock and roll". The idea that this particular type of masculinity defines authentic guitar performance erects several more barriers in regards to female guitarists, including the notion that there are essentially masculine and feminine forms of rock rebellion. This allows any female rock performance featuring characteristics that can be traced to a male artist to be labelled as artificial. The treatment of female electric guitarists as exceptional permits them to be seen as a trend, which gives the detrimental illusion that women musicians have not played a continuous part in rock history. Until society recognizes the 
existence of multiple viable representations of both masculinity and femininity, women will continue to be viewed as outsiders in male-dominated fields. In the meantime, female electric guitarists would do well to heed guitarist Charlie Christian's (1982) advice to fellow musicians in the early days of electrification and continue to play their instruments the way they should be played until they make the rest of the world like it.

\section{Notes}

1. Given this point, the author has consciously chosen to provide little historical detail about specific women who play the electric guitar. For sources dealing with the history and experiences of women in rock, see Bayton, Carson et al., Gaar, and O'Brien.

\section{Acknowledgements}

I continue to be indebted to the girls and women of Girls Rock Denver and the Girls Rock Camp Alliance, whose work and dedication aim to ensure that future female musicians develop the voices and confidence necessary to define their own forms of rock rebellion. This article is an expanded version of the paper, "From Tinkerers to Gods: The Electric Guitar and the Social Construction of Gender," which was presented at the 15th Biennial IASPM International Conference, Liverpool, England, July 2009. Both papers are based on my Master's thesis: 2007. From Tinkerers to Gods: The Electric Guitar and the Social Construction of Gender, University of Colorado, Denver.

\section{References}

Auslander, Philip. 2006. Performing Glam Rock: Gender and Theatricality in Popular Music, University of Michigan Press, Ann Arbor.

Bayton, Mavis. 1998. Frock Rock: Women Performing Popular Music, Oxford University Press, Oxford.

Bayton, Mavis. 1997. "Women and the Electric Guitar" in S. Whiteley ed. Sexing the Groove: Popular Music and Gender, Routledge, New York.

Carson, M., Lewis, T. \& Shaw, S. M. 2004. Girls Rock! Fifty Years of Women Making Music, University of Kentucky Press, Lexington.

Christian, Charlie. 1982. "Guitarmen, Wake Up and Pluck! Wire for Sound; Let 'Em Hear You Play”, Guitar Player, March 1982, p. 50. Published in Down Beat. 10 July 1969. First published in a Chicago news article. 1 December 1939. 
Coates, Norma. 1997. "(R)evolution Now? Rock and the Political Potential of Gender" in S. Whiteley ed. Sexing the Groove: Popular Music and Gender, Routledge, New York.

Daisy Rock Guitars. 2006. 'Tish Ciravolo', 4 March,

<http://www.daisyrock.com/news/tish ciravolo.htm> [Accessed 10 Mai 2010]

Douglas, Susan J. 1999. Listening In: Radio and the American Imagination...from Amos ' $n$ 'Andy and Edward R. Murrow to Wolfman Jack and Howard Stern, Times Books, New York.

Fender Musical Instruments Corporation. 2010. "Electric Guitars Artists Series", $<$ http://www.fender.com/products/search.php?section=quitars\&prod series=Artist [Accessed 11 January 2010]

Frith, S. \& McRobbie, A. 2000. "On the Expression of Sexuality" in D. B. Scott ed. Music, Culture, and Society A Reader, Oxford University Press, New York.

Gaar, Gillian G. 1992. She's a Rebel: The History of Women in Rock \& Roll, Seal Press, Seattle.

Gibson Guitar Corporation. 2010. "Gibson Custom", <http://www2.gibson.com/Products/Electric-Guitars/Gibson-Custom.aspx> [Accessed 11 January 2010]

Gibson Guitar Corporation. 2010. "The Gibson Difference”, $<$ http://www.gibson.com/enus/Lifestyle/ProductSpotlight/GearAndInstruments/Th e\%20Gibson\%20Difference> [Accessed 11 January 2010]

Gibson Guitar Corporation. 2010. "Gibson Guitar Company and Luxury Lingerie Company Agent Provocateur Promote the Gibson Les Paul Goddess Guitar During July 2007", <http://www.gibson.com/en-us/Lifestyle/Features/Godess> [Accessed 11 January 2010]

Gibson Guitar Corporation. 2010. "The Gibson Les Paul Goddess Rocks with Agent Provocateur", <http://www.gibson.com/en-us/Lifestyle/Features/GodessRocks> [Accessed 11 January 2010]

Gibson Guitar Corporation. 2006. "Gibson USA Presents 15 New Guitars for 2006",

$<$ http://www.gibson.com/absolutenm/templates/ gibsonnewstemplate.aspx?articl eid=783\&zoneid=2 $>$ [Accessed 17 April 2010]

Gretsch Musical Instruments. 2010. "Gretsch Guitars Gear", <http://www.gretschguitars.com/gear> [Accessed 11 January 2010]

Halberstam, Judith. 2002. "What's That Smell?: Queer Temporalities and Subcultural Lives" in S. Whiteley and J. Rycenga eds. Queering the Popular Pitch. Routledge, New York. 
Hanna, Kathleen. 2007. "Riot Grrrl Manifesto".

<http://www.infoshop.org/youth/index.php?name=sections\&req=viewarticle\&artid $=25>$ [Accessed 5 October 2007]

Jones, Amelia. 1998. "Postfeminism, Feminist Pleasures, and Embodied

Theories of Art" in Donald Preziosi ed. The Art of Art History: A Critical

Anthology, Oxford University Press, New York.

Keightley, Keir. 1996. “'Turn It Down!' She Shrieked: Gender, Domestic Space, and High Fidelity, 1948-59", Popular Music Vol. 15, No. 2, pp. 149-177.

Kennealy-Morrison, Patricia. 1995. "Rock Around the Cock" in E. McDonnell and A. Powers eds. Rock She Wrote, Delta, New York.

Krantz, Matt. 2009. "Daisy Rock makes guitars just for girls and women”, USA Today, 15 December, <http://www.usatoday.com/money/smallbusiness/2009-1215-daisyrock15 CV N.htm>[Accessed 29 January 2010]

Nochlin, Linda. 1988. "Why Have There Been No Great Women Artists?" in Women, Art, and Power and Other Essays, Harper \& Row, Publishers, New York.

Oldenziel, Ruth. 1999. Making Technology Masculine: Men, Women and Modern Machines in America, 1870-1945, Amsterdam University Press, Amsterdam.

O'Brien, Lucy. 2002. She Bop II: The Definitive History of Women in Rock, Pop and Soul, Continuum, New York.

Padel, Ruth. 2000. I'm a Man: Sex, Gods and Rock 'n' Roll, Faber and Faber, London.

Post, Robert C. 1994. High Performance: The Culture and Technology of Drag Racing, 1950-1990, The Johns Hopkins University Press, Baltimore.

Raha, Maria. 2005. Cinderella's Big Score: Women of the Punk and Indie Underground, Seal Press, Emeryville, CA.

Reynolds, S. \& Press, J. 1995. The Sex Revolts: Gender, Rebellion, and Rock ' $n$ ' Roll, Harvard University Press, Cambridge.

Rhodes, Lisa L. 2005. Electric Ladyland: Women and Rock Culture, Philadelphia: University of Pennsylvania Press, Philadelphia.

Rock 'n' Roll Camp for Girls. 2007. "Girls Rock Camp Alliance”, Supporters, <http://www.girlsrockcamp.org/supporters/grca> [Accessed 10 September 2007]

Rock 'n' Roll Camp for Girls. 2007. "History", About Us; <http://www.girlsrockcamp.org/about/history> [Accessed 10 September 2007]

Rolling Stone. 2006. "The 100 Greatest Guitarists of All Time", $<$ http://www.rollingstone.com/news/story/5937559/the 100 greatest guitarists o f all time $>$ [Accessed 16 April 2006] 
Salomon, Nanette. 1998. "The Art Historical Canon: Sins of Omission" in D. Preziosi ed. The Art of Art History: A Critical Anthology, Oxford University Press, New York.

Sandstrom, Boden. 2000. "Women Mix Engineers and the Power of Sound" in P. Moisala and B. Diamond eds. Music and Gender, University of Illinois Press, Chicago.

Schilt, Kristen. 2003. “'A Little Too Ironic': The Appropriation and Packaging of Riot Grrrl Politics by Mainstream Female Musicians", Popular Music and Society, Vol. 26, No. 1, pp.5-16.

Segal, David. 2004. "No Girls Allowed? In the World of Guitar Boasts, Few Women Let Their Fingers Do the Talking", The Washington Post, 22 August, <http://www.washingtonpost.com/ac2/wp-dyn/A19175-2004Aug20.html> [Accessed 4 March 2006]

Smith, Monica and Gary Sturm, curators. 2006. 'From Frying Pan to Flying V: The Rise of the Electric Guitar', $<$ http://invention.smithsonian.org/centerpieces/guitars $>$ [Accessed 20 February 2006]

Sparkling Lemonade. 2009. "A Young Girl's Dream”. Written and performed at Girls Rock Denver Summer Camp Session, July.

Strohm, John. 2004. "Women Guitarists: Gender Issues in Alternative Rock" in A. Millard ed. The Electric Guitar: A History of an American Icon, The Johns Hopkins University Press, Baltimore.

Takahashi, Yuzo. 2000. "A Network of Tinkerers: The Advent of the Radio and Television Receiver Industry in Japan", Technology and Culture, Vol. 41, No. 3, pp. 460-484.

Waksman, Steve. 1999. Instruments of Desire: The Electric Guitar and the Shaping of Musical Experience, Harvard University Press, Cambridge.

Whiteley, Sheila. 2000. Women and Popular Music: Sexuality, Identity, and Subjectivity, Routledge, New York.

Willie Mae Rock Camp for Girls. 2007. "Mission and History", About Us, <http://www.williemaerockcamp.org/about.html> [Accessed 10 September 2007] 